\title{
The Role of Indigenous Knowledge in Resolving Conflicts Over Grazing Land and Water Resources: The Case of Afar and Karrayyu, Upper Awash
}

\author{
Mebrahtom Guesh(MA in Development Studies) \\ Lecturer, Department of Civics and Ethical Studies, Raya University, P.O. Box 92, Maichew, Ethiopia \\ Biniam Debela(MA in Gender and Development) \\ Lecturer, Department of Civics and Ethical Studies, Raya University, P.O. Box 92, Maichew, Ethiopia
}

\begin{abstract}
Generally speaking pastoral areas are full of conflicts due to lack of natural resources such as grazing land, water and others. This article, therefore, aims at assessing the extent of conflict among the Afars and Karrayyu Oromo agro-pastoralists at the upper Awash and to explore the role of indigenous knowledge in resolving conflict between the two. The study employed both qualitative and quantitative data which was generated from primary and secondary sources. Then convenience sampling used to select the required number of subjects (150). The method of data analysis was both qualitative and quantitative. The SPSS software version 17 was also used. The overwhelming majority of the Karayyu and Afar agro- pastoralists are in conflict with each other over the use of land and water resources. As a result of conflict many pastoralists were killed, the number of livestock decreased. Finally, the article recommends in ensuring community participation in natural resources management and utilization.
\end{abstract}

Keywords:- Pastoralists, Conflict, Indigenous knowledge

DOI: $10.7176 / \mathrm{JCSD} / 46-04$

Publication date:March $31^{\text {st }} 2019$

\section{INTRODUCTION}

\section{Background of the Study}

Conflicts are not confined to particular area. It occurs everywhere in the world and many are losing their lives every year because of armed conflicts (Ogata and Sen, 2003 cited in Bekele Hunde, nd). In the Ethiopian lowlands, outbursts of pastoralist violence have challenged both the federal and regional governments (Hagmann and Alemmayya, 2008).

According to Bekele Hundie (n.d), who has conducted research on conflict between Afar and their neighbors, the pattern of conflict in Afar is complex and several factors are contributing to the perpetuation of conflicts in the region. The Afars are in conflict with many ethnic groups which shares their boundaries like with karrayyu Oromos, Tigrayans, Issa- Somali and Amhara. Accordingly they believe that they lost some of their lands to the Issa such as Mulu, Erer, Afdem, and part of the Alaydeghi plain.

Inter-community conflicts are mostly related to competition over resources such as land, cattle and water points and mostly take the form of individual incidents of theft, murder and rape. "Following the shift to sedentary life, the degree of the Afar-Tigrayan interaction has been increasing. The frequency of intercommunity conflict, at individual level, is thus likely to increase as economic interdependence (particularly in share-cropping) deepens involving more Tigrayans and Afar." (Kelemework, 2011)

Various reasons are attributed to the conflicts in the region and the expansion of other ethnic group such as the Issas which displaced several Afar clans from their homelands, scarcity of resources/ declining resource base in their territory which pushed them to the neighboring territory (Karrayyus in the south), competition over new source of revenues and control of market centers and strategic places. Intensification of livestock raiding, recurrent drought and better access to what does it mean? Technologies are also another causes of conflict in the region among different ethnic groups (Gebre, 2001; Getachewu, 2001 cited in Bekele—n.d).

Some scholars associate conflict in Afar with current political situations. According to Bekele n.d, for example, the extensive land confiscation programs of the Ethiopian state, the ethnic- based federalism adopted in Ethiopia in 1991 increased ethnic groups' awareness of traditional territories, the unstable geopolitical conditions of the Horn countries which facilitated illegal trafficking of firearms, and the high dependence of Ethiopia on the port of Djibouti where the Issas have political dominance over Afars' are all contributing to the perpetuation of conflicts especially between the two ethnic groups.

Dejene (2004) cited in Desalegn et al. emphasized the importance of indigenous institutions in conflict resolution. He indicated that the effectiveness of the araara (Araara is the process of conflict management involving individual clans within and outside the community and basically handled by the council of elders in the community and thus associated with the gadaa system, and called jaarsummaa in some localities) institution 
between the Karrayyu Oromo of the Upper Awash and its neighbouring ethnic groups like the Afar and Argoba.

The Afars believe that all disputes within their ethnic group should be settled peacefully through their customary law called Mad'aa which consists of specified guidelines and rules on how to handle dispute cases, and the elders transfer this customary law on to the young generations. Among Afars every offense has a corresponding compensation payment and the fine and compensation payment varies depending on the part of the body that was harmed. The damage caused to fingers, front and back part of the body, nail injury are given different value. But, Afar customary laws are dynamic and vary from place to place (kelemework, 2006).

Afar elders strongly underscore that all Afars are governed by the same custom (Ada) irrespective of their clan affiliation, area of residence or changes in national politics. The Afar people have a strong sense of respect to the legendary traditional rules and guidelines that descended to them from their predecessors. When a breach of conduct or misbehavior is detected reference is quickly made to such unwritten customary laws the basis of which is the normative framework and values systems entrenched in their culture from time immemorial (Kelemework, 2011).

This paper was discussed the extent of conflict and the role of indigenous institutions in conflict resolution in upper Awash among the Afars and Karrayyu Oromos over grazing lands and water points. It also aimed at describing and discussing the types of informal institutions and the specific mechanisms adopted in the process of resolving violent conflict within the context of intra-Afar and inter-community relations. The organization and structure of the traditional institutions and their potential in conflict resolution will also be discussed.

\section{Statement of the Problem}

Pastoral areas in general are full of conflicts. They have never been places where livelihoods run peacefully and progressively. Access to resources such as grazing land and water sources are the major causes of conflict that are historically documented in these areas (Getachew, 2001; Ayalew, 2001, Markakis, 2004 cited in Bekele, nd). The major causes of conflict among the Afar and the Karrayyu Oromos agro-pastoralists are shortage of pasture and water. Any effort to utilize the pasture inflicts conflict between the Afar and the Karrayyu Oromos agropastoralists. Similarly, conflicts occur when the neighboring ethnic groups intrude either without prior negotiation or when these efforts fail. Most of the conflicts in the region arise because of lack of access to resources such as grazing land and water sources. Clan land often comprises strategic resources such as grazing areas including dry season retreats, browsing resources, and water points. In addition, each clan has also communal graveyard, settlement areas (metaro) and ritual sites. Each clan has a well-established gerontocracy where the decision power regarding land and other natural resources rests on the village council consisting the clan leader, elders, the feima and local wise-men. Based on these customary institutions, every member of the clan, by default, has the right to use the fruits of his clan's land once he has the livestock to utilize the resources. (Bekele, nd).

During prolonged drought pastoralists migrate to distant places controlled by other ethnic groups once informal assessment has been made for the existence of adequate pasture and browse. In this case, negotiation is strictly required (Bekele, nd). But once negotiation is failed, it leads to conflict between the two pastoralist groups.

Even though customary and religious institutions are playing a very significant role, the Ethiopian constitution has, however, limited the mandate of the customary and religious institutions to private and family matters. However, the role of religious institutions is not limited to perform a spiritual mission. It goes beyond that to other domains such as conflict resolution though the role of religious institutions in conflict resolution is a topic that has received little academic attention in general (Appleby 2000:1-3 cited in Meron n.d) and in Ethiopia in particular (Zeleke 2009b:1 cited in Meron,year).

Although the Afar have experienced progresssive incorporation into the Ethiopian state administrative system, including the establishment of peasant associations and modern courts, their indigenous institutions for the resolution of intra-Afar conflict have demonstrated resilience due to both internal and external factors. Unlike the case in the indigenous system, both the procedures and the standards of the court are not readily comprehensible to the Afar. The laws and regulations are promulgated by a higher central body that could not be sensitive to Afar customary law and values (not least due to the multinational composition of Ethiopia itself). The modern court is thus far from transparent to ordinary Afar, and this may entice lack of confidence in its resolutions. Additionally, court verdicts do not normally take into account the extrajudicial context where concern over stable and amicable social relations is often paramount. Lastly, as the court personnel it is largely composed of outsiders; it is often the case that Afar decline to disclose to "strangers" sensitive matters pertaining to their families or property (kelemework, 2011). The general research questions that the research will address are:-what is the extent of conflict in upper Awash among the Afars and Karrayyu Oromos agro-pastoralists and what is the role of indigenous knowledge/institutions in resolving conflict? 


\section{Specific research questions are:}

1. What are the causes and extent of conflict in the upper Awash among Agars and Karrayyu Oromo agro-pastoralists?

2. What are the informal alternative mechanisms/institutions of conflict resolution in upper Awash?

3. What are the roles of indigenous institutions in conflict resolution?

4. What are the resource-based conflicts among the two agro-pastoral groups?

\section{MATERIALS AND RESEARCH METHODOLOGY \\ Description of the study area}

The Afar National Regional State (ANRS) is located in the great East African Rift Valley in the north-eastern part of the country (Tadesse and Yonas, n.d). Afar is one of the nine regional states of the Federal Democratic Republic of Ethiopia. Geographically, the region is situated between $8^{\circ} 40^{\prime}$ to $14^{\circ} 27^{\prime} \mathrm{N}$ and $39^{\circ} 51^{\prime}$ to $41^{\circ} 23^{\prime} \mathrm{E}$. It shares international borders with Eritrea (to the north) and Djibouti (to the northeast). Domestically, Afar borders on the Somali region (to the east), the Oromia region (to the south), the Amhara region (to the west and southwest), and the Tigray region (to the northwest). The region is arid and hot, with annual rainfall usually between $225 \mathrm{~mm}$ and $560 \mathrm{~mm}$ and the daily maximum temperature between 18 and 45 degree Celsius. Transhumant pastoralism is the main economic activity of Afar region. Afar pastoralists keep various types of livestock including camels, cattle, sheep, and goats.

Most of the region is dry and rocky, unsuitable for cultivation. Out of the total area of the region (estimated at $97,250 \mathrm{~km} 2$ ) cultivated and arable land constitutes $5.24 \%$, forest $1.54 \%$, bush and shrub $18.62 \%$, grassland $1.56 \%$, marshy land $2.74 \%$, water bodies $0.63 \%$, and degraded and rocky land $63.7 \%$, (ANRS Capacity Building Bureau, 2003:2 cited in Tadesse and Yonas). The region's altitude ranges from a maximum of 1500m above sea level to a minimum of $116 \mathrm{~m}$ below sea level. The region is frequently exposed to persistent droughts and is classified as one of the drought-affected regions in Ethiopia (Tadesse and Yonas, n.d).

\subsubsection{Data types and Sources}

The study employed both qualitative and quantitative data which was generated from primary and secondary sources. Interview, focus group discussion and questionnaires were used as primary sources of data collection instruments.

\section{Research design}

The study was entirely a survey study. Hence, samples were drawn from the total population and generalization is made about the whole population from the samples selected. The major informants were elders living in the upper Awash basin.

\subsubsection{Target population}

The target population of the study is all who have been, directly or indirectly, participated in conflict and are adversely affected by the conflict occurring in the upper Awash.

\subsubsection{Sampling size and sampling technique}

The population was selected purposefully. Those who are elders and who are supposed to be good informants was selected purposefully from the total population. By considering resource and time limitations, 150 samples were selected as representative. Then convenience sampling is used to select the required number of subjects (150). Both an interview and focus group discussion (consisting of six focus groups discussion three from each ethnic group) was conducted with elders and clan leaders who were believed to be key informants.

\section{Methods of data collection}

The process of data collection was managed by the researchers themselves and by hiring data collectors and supervisors. Both qualitative and quantitative data was gathered through self administered open and close ended questionnaires, interview, and focus group discussion. Primary data was collected through structured questionnaires, focus group discussions and interviews. The questionnaire was tested before implementation for its consistency, logical flow, coding and length, and amended. Enumerators who had completed college studies and who understand and speak the local language (Oromifa) and Qafaraf was recruited. Training on the content of the questionnaires, where, when and how to conduct the interviews with farmers, was given in advance for the enumerators. The questionnaire was translated in to Afarigna and Oromiffa for respondents understanding for correct response to different issues in questionnaire. The Focus Group Discussions have a maximum number of eight and a minimum of six. They are constituted to have a mix of different socio-economic status such as gender and age to minimize biased conclusion. Six focus Group discussions, three from each ethnic group were conducted. On the other hand, secondary data was gathered by assessing all relevant documents and previous researches from different sources that elucidate the extent of conflicts and the role of indigenous institutions in conflict resolution which are of primarily the internet and different documents. 


\section{Method of Data analysis}

The method of data analysis is both qualitative and quantitative. The analyses is largely based on qualitative data obtained through questionnaire, interview and focus group discussions. Qualitative research is a broad approach to study social phenomena. It seeks to understand a given research problem or topic from the perspectives of the local population it involves. It is especially effective in obtaining culturally specific information about the values, opinions, behaviors, and social contexts of particular populations. Quantitative data is also used to a lesser extent. When both qualitative and quantitative method is used together, qualitative research can help us to interpret and better understand the complex reality of a given situation and the implications of quantitative data. We can understand what the people feel and think using qualitative method whereas; Quantitative method is use to know how many of the audience feel or think that way. Thus, the data obtained was arranged in classes or groups based on common characteristics and analyzed accordingly. Those that have qualitative characteristics were described qualitatively and those data which obtained in the form of quantitative phenomenon is analyzed using descriptive statistical units such as mean, mode and median and others. The SPSS software version 17 was used.

\section{RESULTS AND DISCUSSION}

Occurrence of conflicts

Conflicts occur at state, regional, and local levels and involves various actors: governments, nationalist groups, religious groups, and the community (Tadesse and Yonas, n.d). In a similar fashion, about $93 \%$ of the respondents replied that usually the Karayyu and Afar agro- pastoralists are in conflict with each other (Table 1) though the remaining respondents stated that there are no conflicts over the use of water points and grazing lands occurred between the Karayyu and Afar pastoralists. This implies that conflicts over the use of water and grazing land have been the major characteristics of the respondents.

Table 1: Respondent's response for the occurrence of conflicts

\begin{tabular}{|l|c|c|c|}
\hline $\begin{array}{l}\text { Are there grazing land and water points use related conflicts in } \\
\text { your locality? }\end{array}$ & Response & Frequency & Percent \\
\cline { 2 - 4 } & Yes & 140 & 93.34 \\
\cline { 2 - 4 } & No & 10 & 6.66 \\
\cline { 2 - 4 } & Total & 150 & 100.0 \\
\hline
\end{tabular}

Source: Own Survey 2015

According to the majority of the key informant's response, competing use over grazing land and water points were the major factor for the conflicts occurred since centuries. The pastoralists and agro-pastoralists of Awash Fentale and Awash Sebat perceived that the grazing land and water points which are found somewhere in the area belong to them. This indicates that land tenure security is paramount importance for pastoralists and agro-pastoralists. Various findings (For example, Nari, 2000, FAO, 2003, Herrera et al., 2006, Meur et al., 2006, Kimani, 2008, Adisa et al., 2010) stated that ensuring tenure security and equitable sharing of the resources can enhance cooperation and reduce conflicts among agro-pastoralists of Karayu and Awash.

\section{Major Causes of Conflict}

Natural resource conflicts have always been with humans due, in part, to the multiple and competing demands on resources (Anantha et al., 2000, Warner, 2000, Humphreys, 2005, CHF, 2006, FAO, 2009). Natural resource conflicts arise if user groups are excluding themselves from participating in natural resources utilization and management. All of the respondents $(100 \%)$ stated that grazing land and water point related conflicts are the common practices in their surroundings, and it is the most important causes of conflicts. The key informants also confirmed that the absence of water and grazing land for their livestock in their surrounding has been the main cause of their conflicts.

According to the key informants the other possible reasons for the conflicts between the Afars and Karrayu agro-pastoralists have been the absence of well defined land tenure system. For instance the two communities were quarreled by the use of grazing lands around Awash National park and Awash River though these properties belong to the federal government. This indicates that tenure security and land certification have a significant role for peace building and avoiding conflicts among the pastoralists. Different causes are accountable for inter-community and intra-community conflicts. Yohannes et al. (2005) stated that conflicts are triggered by multiple ecological, economic, socio-cultural and political factors rather than single cause. According to them, the most frequent conflicts are linked to competition over access to common grazing and water, and livestock raiding. One of the current causes of conflicts relates to access to grazing pasture and water points, competition over resources, especially during droughts and dry seasons when the nutritional conditions of livestock are generally compromised.

\section{Rate and Intensity of Conflicts}

The form and intensity of conflicts vary widely in space and over time within any community. Conflicts manifest themselves in many ways, ranging from breaking rules to acts of sabotage and violence (Kimani, 2008, FAO, 
2009, Takeuchi and Marara, 2009). Besides almost all of the respondents in the study area (92\%) replied that conflicts over the use of grazing land resources and water points are quite common for centuries (Table 2). Moreover, the majority of key informants confirmed that there is frequent conflict among the Karrayyu Oromo and Awash Afar pastoralists and agro-pastoralists.

Table 2: respondent's response on the rate of conflicts How do you see the occurrence of grazing land and water point use related conflict?

\begin{tabular}{|l|c|c|} 
Rate of conflict & Frequency & Percent \\
\hline Rare & 4 & 2.67 \\
\hline frequent & 138 & 92 \\
\hline sometimes & 8 & 5.33 \\
\hline Total & 150 & 100.0 \\
\hline
\end{tabular}

Source: Own Survey 2015

Insignificant number of the respondents indicated that there were rare $(2.67 \%)$ conflicts and occurred sometimes $(5.33 \%)$ in the last centuries. This again confirms that frequent conflicts have been taking place between Karrayu and Afar pastoralists over the use of water points and grazing lands though this finding contradicts with what we got during focus group discussion. The focus group discussion participants indicated that though there have been conflicts between karrayyu and Afar for long time over the use of grazing land and water resources, currently the problem is solved and the two communities are living together peacefully and trading with each other. And this is what we observed when we were at the field for data. We have seen karrayyus coming to Awash sebat for market which was not the case before.

Majority of the respondents (92\%) indicated that, on average, conflicts occur more than four times per year (Table 3$)$. The remaining respondents $(8 \%)$ noted that less than three times conflicts have been occurred per a year.

Table 3: Respondent's response for frequency of conflict occurred

How many times conflicts are happened per year?

\begin{tabular}{|l|r|r|}
\hline Time & Frequency & \multicolumn{2}{|c|}{ Percent } \\
\hline$\leq 3$ & 12 & 8 \\
\hline$>4$ & 138 & 92 \\
\hline Total & 150 & 100 \\
\hline
\end{tabular}

Source: Own Survey 2015

Various studies have shown that conflicts over natural resources occur at various levels and involve a variety of actors (Holden and Shiferaw Bekele, 2002, Herrera et al., 2006, Baribeau, 2012). These include conflicts among local men and women over the use of water, grazing lands, trees, neighboring communities disputing over the control of woodlands and villages, community-based organizations, governmental and nongovernmental agencies in conflict over the use and management of large forest tracts (Castro, and Nielsen, 2001, Wood, 1993, Kimani, 2008, Wakhungu et al., 2008). As noted above, conflicts can emerge if one of the user groups are excluding from access to natural resources utilization and management.

\section{Consequences of Conflicts}

Conflicts arise when different interests and needs are incompatible (Adams, 2001, Castro, and Nielsen, 2001, IFAD, 2008, Kimani, 2008, FAO, 2009) and causes different problems to the society in particular and the country in general. Such conflicts of interest are inevitable features of all societies. Currently, the scope and magnitude of natural resource conflicts have increased and intensified. These conflicts, if not addressed, can escalate into violence, cause environmental degradation, disrupt projects and undermine livelihoods. According to the respondents and interviewed key informants, the consequences of conflicts were death of people (14.66\%), loss of properties of pastoralists $(13.34 \%)$, decline in livestock production $(72 \%)$ and destruction of other public services (Table 4).

Table 4: consequences of conflicts

\begin{tabular}{|l|l|l|l|}
\hline What consequences have you & Consequences & Frequency & Percent \\
\cline { 2 - 4 } observed from the grazing land and & death of agro-pastoralists & 22 & 14.66 \\
\cline { 2 - 4 } water points use related conflicts so & decline livestock production & 108 & 72 \\
\cline { 2 - 4 } far? & loss of properties of pastoralists & 20 & 13.34 \\
\cline { 2 - 4 } & Total & 150 & 100 \\
\hline
\end{tabular}

Source: Own Survey 2015

The majority of respondents believed that due to frequent fight between pastoralists of Karrayyu Oromo and Afars around Awash many pastoralists were killed and loss their properties. According to the information from the key informants and focus group discussion, the number of livestock per household is decreasing from time to time which results in the decline of livestock products. As a result, majority of the respondents have been food insecure and dependent on foreign aid.

The unfair distributions of land and water points among pastoralists and tenure insecurity are contributing to 
the damage of properties, decline livestock production and death of people. Tenure security coupled with community participation in natural resources management and utilization could reduce conflicts and result in meeting a range of local needs. A report by a World Conservation Union Working Group also confirmed that "in many countries, tenure security and community involvement are proving to be a cost-effective, socially just, and environmentally sound approach to stabilizing natural forests" (Ayele Gebre-Mariam,1994). Conflicts usually result in the loss of human lives, damage to property and disruption of livelihood activities. The long-standing culture of retaliation has a compounding effect and sustains conflict cycles. Pastoralists feel profoundly humiliated if an attack on a family is not revenged. Retaliatory acts receive positive reactions and are often rewarded by the community. The feeling of humiliation and the subsequent retaliatory measures are usually perceived as collective responsibilities of the entire ethnic group concerned (Yohannes et al. (2005). Conflict Management and Resolution Mechanisms

Nearly all of the respondents stated that conflicts are increasing and becoming severe to the pastoralist and agro-pastoralist societies. The interviewed informants and focus group discussion participants noted that a conflict between the Karrayyu and Afar agro-pastoralists was the most usual events. But in recent times it seems that the problem is becoming history. They are able to settle conflicts between them. The two communities are living together peacefully and trading from each other. The karrayyus are coming to the Afar's territory and vice versa.

The informants and focus group discussants believed that indigenous institutions and local knowledge played paramount importance in settling the conflict. They believe that the indigenous knowledge is effective in settling disputes in the area as compared to the formal (court system) way of conflict resolution method. The government played only the role of facilitation in bringing the two sides together and nothing more. Accordingly, indigenous knowledge should be given due emphasis in peace building intervention. According to the key informant's interview, the federal government, regional states, clan leaders and agro-pastoralists are the most responsible groups in the process of conflict management. Moreover, clan leaders have been more preferable compared with others due to the fact that clan leaders can easily understood pastoralist's problem and the pastoralists has a due respect for them and their culture.

Responsible groups for the conflict resolution

Table 5: Responsible organ for the occurrence of conflicts?

\begin{tabular}{lcc}
\hline Responsible group & Frequency & Percent \\
Federal and regional states & 47 & 31.34 \\
Clan leaders & 70 & 46.67 \\
Agro-pastoralists themselves & 33 & 21.99 \\
Total & 150 & 100.0 \\
\hline
\end{tabular}

Source: Own Survey 2015

Hence, the clan leaders have been working as mediator in resolving conflicts occurred between the Karrayyu and Awash pastoralists. The government played a role of facilitation in bringing the disputants around the table.

Conflict prevention and resolution may be more effective if early indicators of impending conflicts can be identified. However, the timing of conflict is usually unpredictable and it is difficult to extract any early warning of conflict indicators. This is because conflicts can be caused by individuals or groups and can occur during the dry or wet seasons. For example, some of the conflicts occur during periods of drought and famine when different groups come to common pasture and water resources, while some occur during marriage and traditional festivals when the demand for livestock raiding and heroism among the community results in killing 'enemies (Yohannes, et al.2005).

All of the respondents $(99.3 \%)$ believed that peaceful and coordinated range land and water points utilization and management would be possible, if the responsible bodies such as pastoralists, NGOs, GOs, and others committed to create awareness on pastoralists, provide land certification like the other parts of Ethiopia, and equitably distribute the resources (Table 6).

Table 6: respondent's response for proper utilization and management of resources

\begin{tabular}{lccc}
\hline Do you think peaceful and coordinated range land and & Response & Frequency & Percent \\
water points utilization possible? & yes & 149 & 99.3 \\
& no & 1 & 0.7 \\
& Total & 150 & 100 \\
\hline
\end{tabular}

Source: Own Survey 2015

Participation of pastoralists at planning, implementation, and monitoring stages during tenure security and land demarcation can reduce conflicts related to natural resources. Moreover, promoting the existing community-based peace-building process by merging existing customary law with the formal institutions 
could be convenient for conflict resolution. A case study conducted by Castro \& Nielsen (2001) revealed that co-management agreements among indigenous people, state agencies, and other stakeholders offer substantial promise as a way of dealing with natural resource conflicts in a participatory and equitable manner. Ingles et al. (1999) and Khalkheili and Zamani (2008) also noted "the promotion of collaborative management is based on the assumption that effective management is more likely to occur when local resource users have shared or exclusive rights to make decisions about and benefit from resource use".

\section{Conflict management systems}

About 93 percent of the respondents noted that indigenous conflict resolution technique such as Gadaa system (Karrayu) and Maxuma (Afar) pastoralist has been the most preferable ways of conflict management in the pastoralist's area as compared to formal way of conflict resolution mechanism (court system). However, few respondents replayed that court system of conflict resolution has been better. (See table 7 below). The focus group discussion and key informants interview also confirmed that indigenous conflict resolution mechanisms have been more effective compared with the court system as indigenous conflict resolution mechanisms played a great role for the settlement of conflicts between the two pastoralist groups which lasts for centuries.

Table: 7 conflict management systems

\begin{tabular}{lcc}
\hline conflict management systems & Frequency & Percent \\
Court system & 11 & 7.34 \\
Indigenous conflict resolution & 139 & 92.56 \\
Total & 150 & 100.0 \\
\hline
\end{tabular}

The key informants stated that clan leaders are acceptable by agro-pastoralists and are skillful in identifying best solution for the conflicts. Indigenous peoples throughout the world have sustained their unique worldviews and associated knowledge systems for millennia. Many of the core values, beliefs and practices associated with those worldviews have survived and are beginning to be recognized as having an adaptive integrity that is as valid for today's generations as it was for generations past. The depth of indigenous knowledge rooted in the long inhabitation of a particular place offers lessons that can benefit everyone, from educator to scientist, as we search for a more satisfying and sustainable way to live on this planet (Barnhardt, \& Kawagley, 2005). Therefore, indigenous conflict resolution system has been the most preferable conflict resolution mechanism. One can understand that the utilization and management of the grazing land and water resources needs to be fairly distributed.

\section{Conclusions and Recommendations Conclusion}

This finding showed that the grazing land and water points are controlled communally either by the federal government or certain pastoralists. As a result, pastoralists who have no water and grazing lands were forced to let their livestock to Awash National park (which is controlled by the federal government) and other grazing lands and water points. Lack of grazing land and water points, absence of well defined grazing land boundary, inequitable natural resources distribution as well as competing needs of these resources are the possible reasons for the conflict between Karrayu and Afar pastoralists and agro-pastoralists. Consequently, recurrent conflicts have been occurring between the Karrayu and Afar pastoralists for centuries which results in declining number of livestock and livestock products as well as deaths of pastoralists. However, currently conflict between karrayyu and Afar pastoralists is not a problem. They are able to settle conflicts between them. They are living together peacefully and trading with each other. Indigenous institutions and local knowledge played paramount importance in settling the conflict. They believe that the indigenous knowledge is effective in settling disputes in the area as compared to the formal (court system) way of conflict resolution method. In order to resolve the ongoing conflicts, the clan leaders have used indigenous conflict resolution systems, Gadaa and Maxuma together. Accordingly, indigenous conflict resolution systems are found to be effective in settling the long lasting conflict. Moreover, the government played a role in mediation as well. Thus, it is concluded that indigenous conflict resolution and peace building systems should be given due emphasis and get recognition by the national government.

\section{Recommendations}

- Both the regional and federal government should work on ensuring tenure security and equitable sharing of the resources and land certification which have a significant role for peace building and avoiding conflicts among the pastoralists.

- Ensuring community participation in natural resources management and utilization. Tenure security coupled with community participation in natural resources management and utilization could reduce conflicts and result in meeting a range of local needs. 
- Indigenous conflict resolution and peace building systems should be given due emphasis and get recognition by the both the regional and federal governments and needs to be documented. System should be devised to use both the court system and Indigenous conflict resolution mechanism together.

- Expand education to reduce the high level of illiteracy. The more the local people are educated, the more they are aware of the negative consequences of conflict.

- Awareness creation on the effect of retaliation. Since retaliatory acts receive positive reactions and are often rewarded by the community, they contribute a lot to trigger conflicts.

\section{References}

Adams,M. (2001).“Tenure security, livelihoods and sustainable land use in Southern Africa,' Keynote Paper, Land Reform and Poverty Alleviation in Southern Africa, Southern Africa Regional Poverty Network, Human Sciences Research Council, Pretoria South Africa, 5 June.

Adisa, R. S. and Adekunle A. O. (2010). "Farmer-herdsmen conflicts: Afactor analysis of socioeconomic conflict variables among arable crop farmers in North Central Nigeria,"Journal of Human Ecology 30: 1-9.

Anantha, K. and G. Ikiara, M. Manundu, W. Nyangena and R. Sinange (2000). "Land tenure, land use, environmental degradation and conflict resolution: a PASIR analysis for the Narok District, Kenya."Working Paper No33. International Institute for Environment and Development, London and Institute for Environmental Studies,Amsterdam.

Ayele Gebre-Mariam(1994). "The alienation of land rights among the Afar in Ethiopia,"Nomadic Peoples, 34:137-146.

Baribeau, G. (2012). "Search for common ground and land conflict in Burundi: A strategic review," January 2012. Washington, D.C.:Search for Common Ground.

Barnhardt, R., \& Kawagley, A. O. (2005). Indigenous Knowledge Systems and Alaska Native Ways of Knowing. Anthropology and Education Quarterly, 36(1), pp. 8-23.

Bekele Hundie. Property Rights among Afar Pastoralists of Northeastern Ethiopia: Forms, Changes and Conflicts, Humboldt University of Berlin.

Castro P. A. and E. Nielsen (2001). "Indigenous people and co-management: implications for conflict management,"Environmental Science and Policy4:229-239.

CHF International (2006). Grass roots Conflict Assessment of the Somali Region, Ethiopia. August 2006. Addis, Ababa.

Food and Agriculture Organization of the United Nations (2009). From Conflict to Peace Building: The Role of Natural Resources and the Environment. Rome: FAO.

Food and Agriculture Organization of the United Nations (2003).Natural Resource Conflict Management Case Studies: An Analysis of Power, Participation and Protected Areas. Rome: FAO.

Hagmann T, Alemmaya Mulugeta (2008). Pastoral conflicts and state-building in the Ethiopian lowlands. Africa Spectrum 43(1):19-37.

Herrera, A. and M. G. da Passano (2006). "Land tenure alternative conflict management. "Land Tenure Service Rural Development Division in collaboration with the Livelihood Support Project, International Land Coalition. Rome: FAO.

Holden, T. S. and Shiferaw Bekele (2002). "Land redistribution, tenure insecurity and intensity of production: a study of farm households in southern Ethiopia, "Land Economics, 78:573-590.

Humphreys, M. (2005). "Natural resources, conflict and conflict resolution: Uncovering the mechanisms,"Journal of Conflict Resolution, 49: 508-537.

Ingles, Andrew and A. Musch, H. Qwist-Hoffmann(1999). The Participatory Process for Supporting Collaborative Management of Natural Resources. Rome: FAO.

International Fund for Agriculture and Development (2008). Improving Access to Land and Tenure Security. Rome: IFAD.

Kelemework Tafere Reda (2011). Conflict and alternative dispute resolution among the Afar pastoralists of Ethiopia. African Journal of History and Culture (AJHC) Vol. 3(3), pp. 38- 47, April 2011

Khalkheili, A. T. and H. G. Zamani (2008). "Farmers'participation in irrigation management: The case of Doroodzan Dam Irrigation Network, Iran,"AgriculturalWaterManagement, 96:859-865.

Kimani,M.J. (2008). "Natural resources conflict in Africa: Is water the new oil?"United Nations Conference on the 'Water and Pasture Menu' in Pastoralist Conflicts in the Greater Horn of Africa,GhoA, $13-$ 14November2008,AddisAbaba.

Meur, L. and P. S. M. Hochet, O.Touré(2006). "Conflict over access to land andwater resources within SubSaharan drylands:Underlying factors, conflict dynamics and settlement processes."Final Research Report, GRET-FAO LEAD.

Nari, Russell (2000). "Land tenure and resource management: amajor challenge inVanuatu,"Pacific Economic Bulletin,Volume15,Number2.National Cent for Development Studies, The Australian National University. 
Tadesse Berhe and Yonas Adaye (nd). The impact of local conflict on regional stability.

Takeuchi, S. and J. Marara (2009). Conflict and Land Tenure in Rwanda.No.1.Tokyo: JICA Research Institute.

Wakhungu, W. J.and C. Huggins, E. Nyukuri (2008). Land Tenure and Violent Conflict in Kenya. Knowledge for Better Livelihood. Nairobi: African Centre for Technology Studies.

Warner, M. (2000). "Conflict management in community-based natural resource projects:Experiences from Fiji and Papua New Guinea."Working Paper135. London; Overseas Development Institute.

Wood, Adrian P. (1993). "Natural resource conflicts in south-west Ethiopia: State,communities, and the role of the national conservation strategy in the search for sustainable development,"Nordic Journal of African Studies 2:83-99. 